\title{
Conservation of biodiversity in private lands: are Chilean landowners willing to keep threatened species in their lands?
}

\author{
Francisco Zorondo-Rodríguez ${ }^{1,2,3^{*}}$, Victoria Reyes-García ${ }^{4}$ and Javier A Simonetti ${ }^{1}$
}

\begin{abstract}
Background: The biological conservation in private lands largely depends upon landowners' willingness to keep populations of wild species on them, an issue highlighted by the Convention on Biological Diversity. In this study, we aim (i) to understand small landowners' behavioural intentions, or relative intensity to adopt a given behaviour, towards threatened wildlife and (ii) to assess the role of local ecological knowledge, awareness of protected area, and forest ownership on landowners' behavioural intentions towards threatened biodiversity. We interviewed peasants living around Los Queules National Reserve in Central Chile.

Results: Interview results showed that behavioural intentions towards threatened species were species-dependant. Results also showed that higher ecological knowledge and awareness of a protected area were associated with positive behavioural intentions towards wildlife. Peasants who owned land with larger forest cover reported positive behavioural intentions towards wildlife more frequently than peasants with less forest cover on their lands, although associations were not consistent across species.

Conclusions: We conclude that (i) opportunities for getting peasants to support species conservation depend on the particular species and vary across peasants and (ii) there is a relevant social heterogeneity among peasants in terms of behavioural intentions towards species. As both factors likely influence conservation outcomes, they should be considered in the design of biodiversity conservation efforts.
\end{abstract}

Keywords: Attitude; Central Chile; Human-nature relationship; Maulino forest; Peasant

\section{Background}

Interactions between threatened wildlife and humans are a major issue in biological conservation (Messmer 2009; Leong 2010). Both negative and positive interactions between wildlife and humans can spring up in lands where threatened species overlap with human settlements (Raymond and Olive 2008; Wallace et al. 2008; Leong 2010). In those areas, the success of conservation plans largely depends upon people's willingness to accept the presence of threatened species around them (Wallace et al. 2008; Messmer 2009; Moon and Cocklin 2011). People's behavioural intentions towards wild species, or the person's relative strength of intention to adopt

\footnotetext{
* Correspondence: francisco.zorondo@gmail.com

1 Departamento de Ciencias Ecológicas, Facultad de Ciencias, Universidad de Chile, Casilla 653, Santiago 7800003, Chile

${ }^{2}$ Institut de Ciència i Tecnologia Ambientals, Universitat Autònoma de Barcelona, Bellaterra, Barcelona 08193, Spain

Full list of author information is available at the end of the article
}

a given behaviour towards species (Mc Cleery 2009), have become a pivotal issue for the management of threatened biodiversity. In fact, the assessment of this issue has been included as a strategic target by the 2011 to 2020 Convention on Biological Diversity (CBD) for biodiversity conservation.

Despite the importance of the topic, there is poor scientific evidence regarding people's perception of biodiversity and wildlife-human interactions in Chile. The few studies on the topic mainly focus on carnivores and their interactions with people. For instance, researchers have argued that peasants have reported conflicts with cougars (Puma concolor), kodkods (Leopardus guigna), and foxes (Lycalopex culpaeus and Lycalopex griseus), species that attack livestock (Franklin et al. 1999; Sanderson et al. 2002; Silva-Rodríguez et al. 2009). Differently, visitors of Chilean protected areas have reported positive willingness to conserve species, including

\section{它}


carnivores (Cerda and Losada 2013). But evidence regarding other species is scant. In this context, the lack of empirical data on human-wildlife interactions becomes a weakness to address the management of threatened wildlife, and the understanding of those interactions arises as a challenge for achieving well-established biological conservation plans in Chile, particularly when the conservation of threatened species strongly depends upon private lands.

Three additional reasons highlight the relevance of studying local landowners' behavioural intentions towards threatened species.

First, the highly diverse and endemic biota of Chilean territory has been disturbed by human activities since the colonial period. Chile holds one of the highest levels of replacement of old-growth forest by forestry plantations (Clapp 2001). In fact, human activities are considered one of the main threats to Chilean biodiversity (Simonetti 1994; Muñoz et al. 1996; Clapp 2001) and their negative impacts are a major environmental problem (Simonetti 1994). In this respect, the social dimension of biodiversity conservation seems pivotal.

Second, the efforts to conserve Chilean biodiversity have been traditionally carried out in protected areas under the National Protected Areas System of the State (SNASPE, for its acronym in Spanish). However, many protected areas are not large enough to maintain viable wild populations of some species (Mella and Simonetti 1994; Pauchard and Villarroel 2002; Acosta-Jamett et al. 2003). In this scenario, the lands surrounding the protected areas become a key element for the success on conservation of Chilean biodiversity.

Last, since most lands located outside Chilean protected areas belong to private landowners (Squeo et al. 2012), the success of conservation actions largely depends upon their collaboration. Although some initiatives aim to include private lands into a system of biodiversity protection (Sepúlveda 2004; Espinoza 2010), most private lands remain unprotected and devoted to productive or extractive uses. Therefore, any effort to strengthen biodiversity conservation in private lands surrounding officially protected areas should assess the interactions between landowners and the biodiversity on their lands.

What are the behavioural intentions of landowners towards threatened species? Do local communities accept the presence of threatened species in their private lands? What are the species better accepted by local people and, hence, that can be more successfully included in plans for biodiversity conservation in private lands? Chilean wildlife managers and conservation biologists do not have answers for these kinds of questions yet. In this article, we address them by examining behavioural intentions of landowners, represented by peasants, in Central Chile. After exploring peasants' behavioural intentions towards a set of threatened species, we estimate the potential associations of behavioural intentions with three factors that might play a key role in the design of strategies for biological conservation in private lands: local ecological knowledge, awareness of local protected areas, and forest surface owned. As case study, we use information collected through a survey with peasants living in the threatened Maulino forest of Central Chile. By addressing these issues, we hope to contribute to the fulfilment of the first target of the CBD's strategy for Chilean biodiversity.

\section{Methods}

\section{Study site: the Maulino forest and the local populations}

Maulino forest is one of the Chilean ecosystems most strongly modified, namely, by its replacement by agricultural lands and pine plantations, as well as by extractions of wood resources (Grez 2005; Bustamante et al. 2006). Deforestation rates are high, although they declined during 1990 to 2007 as compared to 1975 to 1990 (Nahuelhual et al. 2012). Nowadays, Maulino forest is recognized as a hotspot for biological conservation at national (Muñoz et al. 1996) and international levels (Myers et al. 2000). Los Queules National Reserve, with a surface of only $147.3 \mathrm{ha}$, is one of the two protected areas established in the Maulino forest (Figure 1). The surface of the Reserve does not meet the ecological requirements to maintain local biodiversity (e.g. Acosta-Jamett et al. 2003), and the private lands surrounding the Reserve and where high levels of biological diversity still exist (Grez 2005; Bustamante et al. 2006) contribute to that end. Due to the current level of fragmentation, all fragments, independent of surface and location, are important to achieve the conservation of Maulino forest and its biodiversity. In this context, the site constitutes a suitable site to study the willingness of landowners to accept wildlife in their lands.

Lands covered with Maulino forest are owned by forestry companies and peasants. Forestry companies maintain Maulino forest fragments surrounded by large surfaces of pine plantations. According to the current environmental certifications, to achieve environmental certifications, forestry companies should conserve forest fragments located in their properties. Peasants, who are the focus of this study, have a subsistence economy based on agriculture and animal husbandry. Most of them live under the official poverty line. To support their livelihood and household economy, peasants also gather a set of minor natural products (i.e. firewood, charcoal, Chilean hazel, and mushrooms) from Maulino forest fragments. For many peasant families, the commercialization of natural resources is an important source of cash, representing almost one third of the household's income (Zorondo-Rodríguez and Simonetti, unpublished data).

Peasant's uses of local biodiversity are legally controlled by government agencies. The management of Maulino 


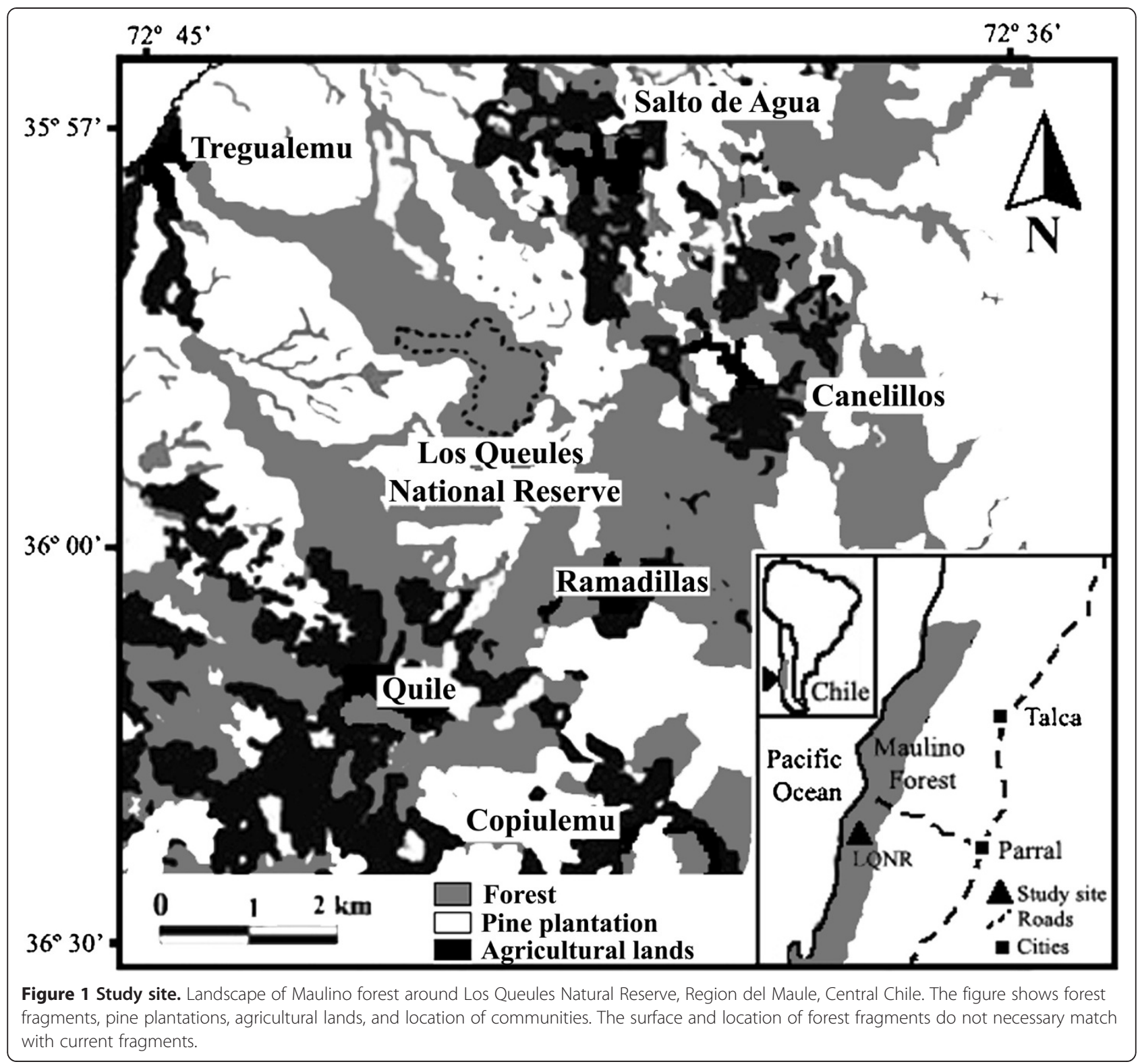

forest fragments is controlled by National Forest Corporation (CONAF). Peasants must submit a management plan to obtain the right to extract natural resources. Through those management plans, CONAF regulates the trees to be cut and the quantities of forest products to be extracted. The Agricultural and Livestock Service of Chile (SAG) prohibits the hunting of native species classified as endangered, vulnerable, rare, as well as those of least concern or those that present low population densities (Servicio Agricola Y Ganadero SAG 2012). SAG also prohibits the hunting of species recognized as beneficial for agricultural and forestry or for maintaining the balance of natural ecosystems.

\section{Data collection}

We conducted our study between November 2004 and March 2005 in the seven peasant settlements located around the Reserve $\left(35^{\circ} 59^{\prime} \mathrm{S}\right.$ to $\left.72^{\circ} 41^{\prime} \mathrm{W}\right)$ in the Región del Maule, Central Chile (Figure 1). The settlements included Canelillos, Copiulemu, Quile, Quilicura, Ramadillas, Salto de Agua, and Tregualemu, all located between 4 and $7 \mathrm{~km}$ from the Reserve. We visited a total of 37 households in those seven settlements, which, according to the 2002 census, represented $15 \%$ of the households located in the study area. This percentage of representation is similar to other studies on the topic (see Clark and Finley 2007; Raymond and Olive 2008). 
To collect data, we applied a semi-structured questionnaire to one of the household heads. If more than one person from the same household were willing to answer our survey, we requested to interview just one of them. The questionnaire was designed on the base of our prior field observations and awareness of the zone and it was tested with a different sample. The questionnaire included a first section to estimate behavioural intentions towards a set of threatened species from Maulino forest. To proxy behavioural intentions, we asked 'Imagine you encounter a [species local name]. What will you do?' We then probed informants to elaborate on the reasons for the stated behavioural intention. Informed consent was obtained from the participants included in the study.

We used the same question to ask about (a) four plant species: queule (Gomortega keule (Molina) Baillon), pitao (Pitavia punctata Molina), and two different species of southern beeches locally known as hualo (Nothofagus glauca (Phil.) Krasser) and roble (Nothofagus obliqua (Mirb.) Oerst.) and (b) five animal species: pudu (Pudu puda Molina), Chilean pigeon (Columba araucana Lesson), culpeo fox (L. culpaeus Molina), grey fox ( $L$. griseus Gray), and kodkod (L. guigna Molina). For the sake of simplicity, we use the term 'biota' when referring to the nine species in the list. We also asked about (c) two general terms related to local biodiversity: Maulino forest and wild animals.

Species were selected to represent a range of species locally endangered and on the basis of their conservation status and local ecological conditions. For instance, according to the national red list, queule and pitao are 'endangered' species; hualo, kodkod, and pudu are 'vulnerable'; and both foxes and Chilean pigeon are 'least concern' species (Benoit 1989; Glade 1993). It is also important to note that queule and pitao are both monotypic species. Although roble, foxes, and Chilean pigeon are not included in the national red list, they are potentially threatened in the area due to high fragmentation and loss of habitat. Research suggests that forest fragments lodge valuable biodiversity, including endemic and endangered species (Grez et al. 2006; Stoll et al. 2006). Further, peasants' verbal communications during our field work confirm that several of the species included in this study (e.g. foxes, kodkods, pudus, Chilean pigeons) have been seen in the peasants' fragments.

The second section of the questionnaire included three questions about (i) local ecological knowledge, (ii) awareness about the Reserve, and (iii) hectares of forest owned. We used the recognition of a set of local species as a proxy of local biodiversity knowledge. Specifically, we assessed informants' ability to identify plant species through leafs and branches and animal species through pictures. The test included the nine threatened species mentioned above plus avellano (Gevuina avellana Molina), peumo (Cryptocarya alba (Mol.) Looser), Chilean bellflower (Lapageria rosea Ruiz et Pav), and green-backed firecrown (Sephanoides sephaniodes Molina). For each informant, we coded as 1 each species known. We then summed the number of known species to create an index of knowledge that captures how many species the informant recognized. To estimate the awareness of the Reserve, we asked informants whether they knew the existence of any protected area and their specific location. We then created a dummy variable that took the value of 1 if the informant gave a correct answer and 0 otherwise. The surface of forest in the property was self-reported by informants.

\section{Data analysis}

\section{Behavioural intentions towards threatened biota}

We coded the informant's behavioural intentions towards species as positive (1) if the reported intended action was meant to have a positive effect on the species population (e.g. preserving and taking care) or negative $(-1)$ if the effects could damage the species' individuals (e.g. cutting, hunting, and replacement for pine plantations). If the reported action presumably had no effect on the species (e.g. look at it) or if the person was unsure of her/his behavioural intentions (e.g. do not know), we coded the variable 0. No informant expressed simultaneously positive and negative intentions towards a given species. Likelihood-ratio chi-square analyses were used to compare the frequency of the three types of behavioural intentions between pairs of species.

\section{Behavioural intentions versus local ecological knowledge, awareness of the Reserve, and forest ownership}

We ran ordered probit regression models to understand the association between behavioural intentions and the three measured factors. We use ordered probit model because our outcome variable, behavioural intention, has categorical values. As explanatory variables, we used the number of recognized species, awareness of the Reserve, and forest ownership (in natural logarithm of hectares). We ran pairwise correlations to discard potentially autocorrelated explanatory variables.

\section{Results}

\section{Description of the sample}

About half of the people in the sample (51.4\%) were men. The average age of the informants was 53.1 years $(\min =29, \max =85)$. The level of schooling among individuals was very low: $56 \%$ of informants reported they had only attended primary school.

\section{Local ecological knowledge, awareness of the Reserve, and forest ownership}

In average, peasants recognized 8.2 of a total of 13 species $(\min =1 ; \max =12)$. The species most commonly identified were the Chilean bellflower (100\% of the sample) and 
the Chilean hazel (94\%). The species less commonly identified were the grey fox (29.7\%) and the kodkod (29.7\%) (Table 1). The Reserve was known by $59 \%$ of the informants. On average, informants owned 15.6 ha of forest $(\min =0, \max =300)$, but the range of values suggests a large variability on forest surface ownership. There were five individuals who reported not owning any forest and one who owned 300 ha (Table 1).

\section{Behavioural intentions towards threatened species}

Positive behavioural intentions towards species included responses such as 'to protect,' 'to preserve, 'to take care', and 'to leave free'. Negative behavioural intentions included responses such as 'to extract wood and charcoal' when asking about forest and plants and 'to hunt', 'to chase away', and 'to kill' when referring to animals. According to the results of likelihood-ratio analysis shown in Table 2, pudu, Chilean pigeon, and wild animals received mainly positive behavioural intentions from peasants. The frequency of positive behavioural intentions towards these three species statistically differed from other species (Table 2). Differently, roble and hualo trees were the species receiving more negative behavioural intentions $(>60 \%)$ among peasants.

\section{Behavioural intentions versus local ecological knowledge, awareness of the Reserve, and forest ownership}

After confirming that explanatory variables were not autocorrelated, two noteworthy results arose from ordered probit regressions as shown in Table 3. First, higher local knowledge, higher awareness of LQNR, and larger surfaces of forest owned were significantly associated with positive behavioural intentions towards threatened species. Second, associations between behavioural intentions and the three explanatory variables differed across species. In particular, higher local knowledge was significantly associated to positive behavioural intentions towards Chilean pigeon (coefficient $=0.21, p=0.04$, row [b] of Table 3), queule (coefficient $=0.14, p=0.09$, row $[\mathrm{g}]$ of Table 3 ), pitao (coefficient $=0.22, p=0.005$, row [h] of Table 3 ), and hualo (coefficient $=0.17, p=0.08$, row [g] of Table 3 ). The

Table 1 LEK, awareness of Los Queules National Reserve, and forest ownership among peasants $(n=37)$

\begin{tabular}{ll}
\hline Variables & Score \\
\hline${\text { Local ecological knowledge }(L E K)^{a}}^{a}$ & $8.2(\min =1 ; \max =12)$ \\
Awareness of LQNR $^{\mathrm{b}}$ & $22(59.5)$ \\
Forest ownership $^{c}$ & $15.6(\min =0 ; \max =300)$ \\
\hline
\end{tabular}

${ }^{a}$ Number species, among those listed, known by peasants: Chilean bellflower (Lapageria rosea), avellano (Gevuina avellana), roble (Nothofagus obliqua), peumo (Cryptocarya alba), green-backed firecrown (Sephanoides sephaniodes), pudu (Pudu puda), culpeo fox (Lycalopex culpaeus), queule (Gomortega keule), hualo (Nothofagus glauca), Chilean pigeon (Columba araucana), pitao (Pitavia punctata), grey fox (Lycalopex griseus), kodkod (Leopardus guigna); ${ }^{\mathrm{b}}$ awareness of LQNR by peasants $(1=y e s) ;{ }^{c}$ hectares of forest in the private land. awareness of LQNR was associated in a positive and statistically significant way to behavioural intentions towards wild animals (coefficient $=1.02, p=0.04$, row [c] of Table 3). Positive and significant associations were also found between forest ownership and behavioural intentions towards pudu (coefficient $=2.32, p=0.01$, row [a], Table 3), wild animals (coefficient $=0.4, p=0.06$, row [c], Table 3), Maulino forest (coefficient $=0.29, p=0.09$, row [f], Table 3), and hualo (coefficient $=0.29, p=0.08$, row [j], Table 3). Last, behavioural intentions towards culpeo fox, grey fox, kodkod, and roble were not associated to any explanatory variable in our model (rows [d], [e], [i], and [k] of Table 3).

\section{Discussion and conclusion}

Conservation of threatened biodiversity in private lands could be jeopardized by lack of landowners' support to the presence of wildlife in their lands (Mc Cleery 2009; Messmer 2009; Poudyal and Hodges 2009; Moon and Cocklin 2011). Our results suggest that this could be the case in Central Chile, particularly in the Maulino forest, although our results also provide two main nuances to this finding. First, positive and negative behavioural intentions change across threatened species. Second, behavioural intentions are positively associated to local ecological knowledge, awareness of the Reserve, and forest ownership, although these associations also vary across species.

Our finding on dissimilar behavioural intentions of peasants across species suggests that different species may require different management approach to achieve their conservation. For instance, local peasants showed more negative than positive behavioural intentions towards roble and hualo and more positive than negative intentions towards pudu and Chilean pigeon. Particularly, roble and hualo might be socially threatened in more than $60 \%$ of the private lands from Maulino forest. We argue that negative behavioural intentions are associated with historical uses of Nothofagus species as main sources of wood and charcoal (Clapp 2001). In fact, these uses are frequently referred as the main threats towards Nothofagus species in Chile (Benoit 1989). The same explanation might apply to the case of Maulino forest.

It is important to note that queule, one of the most endangered Chilean vascular plants (Benoit 1989), received a similar frequency of negative and positive behavioural intentions. Due the critical conservation status of queule, we consider that negative behavioural intentions are worrisome. Our results suggest that despite the protective measures taken, queule extraction might currently occur in the area. In fact, in a study conducted in the same site, Muñoz-Concha and Garrido-Werner (2011) have found a set of traditional uses of queule, reporting that queule's wood harvesting was frequent until recent times. So, results suggest that there might be a pressure 
Table 2 Behavioural intentions towards threatened Chilean species reported by peasants $(n=37)$ from Maulino forest

\begin{tabular}{|c|c|c|c|c|c|c|c|c|c|c|c|c|c|c|}
\hline \multirow{2}{*}{$\begin{array}{l}\text { Species (local name } \\
\text { (scientific name)) }\end{array}$} & \multicolumn{3}{|c|}{ Behavioural intentions $n(\%)$} & \multicolumn{11}{|c|}{ Likelihood-ratio tests between species $^{a}$} \\
\hline & Positive & Neutral & Negative & Ppud & $\mathrm{Ca}$ & WA & Lc & Lgr & MF & Gk & Ppun & Lgu & $\mathrm{Ng}$ & No \\
\hline Pudu (Pudu puda) & $35(94.6)$ & $2(5.4)$ & $0(0.0)$ & - & $7.5^{*}$ & 1.4 & $8.1^{*}$ & $9.8^{* *}$ & $28.7^{* *}$ & $27.9^{* *}$ & $22.1^{* *}$ & $16.2^{* *}$ & $43.9^{* *}$ & $46.5^{* *}$ \\
\hline $\begin{array}{l}\text { Chilean pigeon (Columba } \\
\text { araucana) }\end{array}$ & $31(83.8)$ & $1(2.7)$ & $5(13.5)$ & & - & 1.5 & $8.1^{*}$ & $9.8^{* *}$ & $9.8^{* *}$ & $10.5^{* *}$ & $19.9^{* *}$ & $16.3^{* *}$ & $20.5^{* *}$ & $22.5^{* *}$ \\
\hline Wild animals & 31 (83.8) & $0(0.0)$ & $6(16.2)$ & & & - & $5.5^{*}$ & $9.8^{* *}$ & $9.8^{* * *}$ & $31.4^{* *}$ & $26.7^{* *}$ & $15.9^{* *}$ & $17.2^{* *}$ & $19.1^{* *}$ \\
\hline Culpeo fox (Lycalopex culpaeus) & $22(59.5)$ & $0(0.0)$ & $15(40.5)$ & & & & - & 1.7 & 1.7 & 4.5 & $31.3^{* *}$ & 3.7 & $3.5^{* * *}$ & $4.4^{*}$ \\
\hline Grey fox (Lycalopex griseus) & $19(51.4)$ & $1(2.7)$ & $17(45.9)$ & & & & & - & 0.0 & 1.1 & $26.8^{* *}$ & 0.9 & 3.0 & 3.7 \\
\hline Maulino forest & $19(51.4)$ & $1(2.7)$ & $17(45.9)$ & & & & & & - & 1.1 & $26.8^{* *}$ & 0.89 & 3.1 & 3.7 \\
\hline Queule (Gomortega keule) & $18(48.7)$ & $3(8.1)$ & $16(43.2)$ & - & & & & & & - & $19.5^{* *}$ & 1.9 & $5.9^{* * *}$ & $6.6^{*}$ \\
\hline Pitao (Pitavia punctata) & $18(48.7)$ & $16(43.2)$ & $3(8.1)$ & & & & & & & & - & $12.4^{* *}$ & $40.1^{* *}$ & $41.6^{* *}$ \\
\hline Kodkod (Leopardus guigna) & $15(40.5)$ & $1(2.7)$ & $21(56.8)$ & & & & & & & & & - & 1.5 & 1.7 \\
\hline Hualo (Nothofagus glauca) & $14(37.8)$ & $0(0.0)$ & $23(62.2)$ & & & & & & & & & & - & 0.06 \\
\hline Roble (Nothofagus obliqua) & $13(35.1)$ & $0(0.0)$ & $24(64.9)$ & & & & & & & & & & & - \\
\hline
\end{tabular}

${ }^{a}$ Columns in likelihood-ratio tests between species correspond to each species in the list. Level of significance at ${ }^{*} p<0.1,{ }^{* *} p<0.05$, and ${ }^{* * *} p<0.01$.

over queule and Nothofagus species that need to be attended by Chilean conservation agencies.

The findings regarding the three carnivore species included in this study (i.e. culpeo, gray foxes, and kodkod) slightly differ from the previous studies. In general, carnivores are largely rejected by peasants and perceived as problematic species. As a consequence, carnivores typically hold a very low social support for their conservation (e.g. Lucherini and Merino 2008; Sanderson et al. 2002; Silva-Rodríguez et al. 2009). In comparison, we found relatively low levels of rejection of carnivores as compared to other studies, as only about $56 \%$ peasants displayed negative behavioural intentions towards carnivores. Despite this relatively low level of rejection and considering the current status of local populations and the loss of habitats (e.g. Acosta-Jamett et al. 2003; Galvez et. al. unpublished), our findings indicate that negative behavioural intentions towards carnivores are still a challenge for the success of conservation efforts of carnivores in private lands. As one of the main explanations justifying negative behavioural intentions towards carnivores is poultries predation (see also Sanderson et al. 2002; Silva-Rodríguez et al. 2009), conservation plans aiming at increasing the probability acceptance of carnivores among people should directly address this issue.

We argue that the assignation of different behavioural intentions towards species might be determined by the valuation of ecological attributes of species and their

Table 3 Behavioural intentions versus LEK, awareness about LQNR, and forest ownership, among peasants (n = 37) from Central Chile

\begin{tabular}{|c|c|c|c|c|}
\hline \multirow[t]{2}{*}{ Behavioural intentions towards } & \multirow[t]{2}{*}{ Model } & \multicolumn{3}{|c|}{ Explanatory variables } \\
\hline & & LEK^ & Awareness about LQNR^ & Ln of forest ownership \\
\hline Pudu (Pudu puda) & [a] & $0.01(0.12)$ & & $2.32(0.92)^{*}$ \\
\hline Chilean pigeon (Columba araucana) & {$[b]$} & $0.21(0.10)^{*}$ & $0.99(0.66)$ & $0.05(0.12)$ \\
\hline Wild animals & [c] & $-0.15(0.14)$ & $1.02(0.51)^{*}$ & $0.40(0.21)^{* *}$ \\
\hline Culpeo fox (Lycalopex culpaeus) & [d] & $0.12(0.10)$ & $0.08(0.46)$ & $0.01(0.16)$ \\
\hline Grey fox (Lycalopex griseus) & [e] & $0.13(0.11)$ & $0.21(0.46)$ & $0.00(0.16)$ \\
\hline Maulino forest & {$[f]$} & $0.09(0.09)$ & $0.64(0.50)$ & $0.29(0.17)^{* *}$ \\
\hline Queule (Gomortega keule) & [g] & $0.14(0.08)^{* *}$ & $-0.35(0.44)$ & $0.16(0.16)$ \\
\hline Pitao (Pitavia punctata) & {$[\mathrm{h}]$} & $0.22(0.08)^{* * *}$ & $-0.24(0.40)$ & $-0.06(0.09)$ \\
\hline Kodkod (Leopardus guigna) & [i] & $0.10(0.11)$ & $0.02(0.48)$ & $0.09(0.16)$ \\
\hline Hualo (Nothofagus glauca) & [j] & $0.17(0.09)^{* *}$ & $-0.20(0.53)$ & $0.29(0.17)^{* *}$ \\
\hline Roble (Nothofagus obliqua) & {$[\mathrm{k}]$} & $0.11(0.09)$ & $0.14(0.49)$ & $0.18(0.12)$ \\
\hline
\end{tabular}

ALEK: Local Ecological Knowledge, LQNR: Los Queules National Reserve. Models, in rows, are ordered probit regressions. Cells show the coefficients of the associations and, in parenthesis, standard errors. Empty cell under 'Awareness about LQNR' refers to the omitted variable from the model because it completely explains the distribution of behavioural intentions frequency. Level of significance at ${ }^{*} p<0.1,{ }^{* *} p<0.05$, and ${ }^{* * *} p<0.01$. 
relations with human activities, including household sources of livelihoods, health, nutrition, security, or agriculture. For instance, in general, positive behavioural intentions towards species might be related to moralistic (i.e. spiritual reverence and ethical concern for nature) or naturalistic (i.e. direct experience and exploration of nature) values. Our results also suggest that negative behavioural intentions towards threatened plant species might be motivated by utilitarian value (i.e. practical and material exploitation of nature), mainly, due to extraction of wood. For the case of carnivores, negative behavioural intentions may be determined by negativistic values (i.e. fear, aversion, alienation from nature) by the predation over domestic animals.

Our results dovetail with other studies providing evidence for a positive association between wildlife conservation behavioural intentions and local ecological knowledge and awareness of protected areas (Clark and Finley 2007; Poudyal and Hodges 2009; Mobley et al. 2010). Our results, however, also highlight that those associations might not be significant for all species. We found that higher local ecological knowledge is associated with positive behavioural intentions only for queule and pitao. A plausible explanation for this finding relates to the effect that the distribution of the species (i.e. its rarity or abundance) might have on people's attitudes and behaviours. Leong (2010) suggests that as species increase in abundance (becoming common), people's positive behaviours and attitudes towards them - and therefore efforts for their conservation - decrease. In this sense, the rarity of queule and pitao - much less common than the other species - might mediate peasants' associations between intentions and knowledge.

The awareness of the Reserve was associated with positive behavioural intentions only towards Maulino forest, Pudu, and Chilean pigeon. A plausible explanation for this association, and its dissimilarity across species, might be related to the local perceptions of protected areas' conservation objectives. Since the largest forest fragment in the zone is located in the Reserve and since, differently than other species, both pudu and Chilean pigeon are more likely to inhabit native forests, like the forest in the Reserve (Simonetti 2006), people might relate the Reserve with the native forest and with the species frequently observed in it. Our findings then signal the relevance of awareness of species and protected areas as a strategy to influence behavioural intentions towards species, such as has been emphasized by CBD. Given our results, a plausible approach to increase positive behaviours on conservation could be to conduct environmental education oriented to increase knowledge about species and awareness on protected areas among local people. However, such approach should also consider differences across species.
Last, we propose two plausible explanations related to association between behavioural intentions and forest ownership. First, previous researches suggest that perceiving benefits from the forest might trigger conservation behaviours (Dolisca et al. 2009; Moon and Cocklin 2011). In our case study, peasants have a subsistence economy with high reliance on forest resources, so forest fragments in private lands might be perceived as an economic benefit source for the household. Hence, the interaction between forest fragments and local landowners might lead positive behaviours for conservation among peasants. Second, and in an opposite direction, positive behaviours towards wildlife might have secured the maintenance of forest fragments in private lands. People who have more positive behaviours towards biodiversity might have managed their remaining forests fragments in order to conserve them.

Researchers and conservation agencies have strongly emphasized the need to manage biodiversity in private lands. Our findings show that different threatened species in a given area would have different opportunities in private lands. So, successful conservation in private lands needs a strategy that differentiates across species in the effort to get social support for their conservation. Our study points out that research and conservation efforts in private lands should focus on the interaction between each species and the local communities. The findings of such analysis can help understand the role of landowners, peasants in our case, in conservation and will guide the future management plans for threatened biodiversity. Last, conservation efforts in private land should strongly focus on measures aimed at both increasing positive behaviours towards wildlife and decreasing negative practices towards the threatened species.

\section{Competing interests}

The authors declare that they have no competing interests.

\section{Authors' contributions}

FZR designed the methodology, collected and analyzed the data, and drafted the manuscript. VRG contributed to the analysis of data and writing the manuscript. JAS participated in the design of methodology, analysis of data, and writing the manuscript. All authors read and approved the final manuscript.

\section{Acknowledgements}

We greatly appreciate the hospitality, kindness, and friendship of people from communities. We appreciate the comments by A. Luz, I. Ruiz, C. Gonzalez, N. Gálvez, and C López. We thank CONAF for providing logistic facilities.

\section{Author details}

1 Departamento de Ciencias Ecológicas, Facultad de Ciencias, Universidad de Chile, Casilla 653, Santiago 7800003, Chile. Institut de Ciència i Tecnologia Ambientals, Universitat Autònoma de Barcelona, Bellaterra, Barcelona 08193 , Spain. ${ }^{3}$ Proyecto MMA/GEF-PNUD Creación de un Sistema Nacional de Áreas Protegidas para Chile: Estructura Financiera y Operacional, San Martin 73, Ministerio del Medio Ambiente, Santiago 8340515, Chile. ${ }^{4}$ ICREA and Institut de Ciència i Tecnologia Ambientals, Universitat Autònoma de Barcelona, Bellaterra, Barcelona 08913, Spain. 
Received: 13 November 2012 Accepted: 20 December 2013

Published: 26 March 2014

\section{References}

Acosta-Jamett G, JA S, Ro B, Dunstone N (2003) Metapopulation approach to assess survival of Oncifelis guigna in fragmented forests of central Chile: a theoretical model. Mastozoo logía Neotrop 10:217-229

Benoit I (1989) Red list of Chilean terrestrial flora. Corporación Nacional Forestal. Impresora Creces Ltd., Santiago, Chile, 151 p

Bustamante RO, Grez A, JA S (2006) Efectos de la fragmentación del bosque Maulino sobre la abundancia y diversidad de especies nativas. In: Grez AA, Simonetti JA, Bustamante RO (eds) Biodiversidad en ambientes fragmentados de Chile: patrones y procesos a diferentes escalas. Editorial Universitaria, Santiago, Chile, pp 83-97

Cerda C, Losada T (2013) Assessing the value of species: a case study on the willingness to pay for species protection in Chile. Environ Monit Assess 185:10479-10493

Clapp RA (2001) Tree farming and forest conservation in Chile: do replacement forests leave any originals behind? Soc Nat Resour 14:341-356

Clark WA, Finley JC (2007) Determinants of water conservation intention in Blagoevgrad, Bulgaria. Soc Nat Resour 20:613-627

Dolisca F, Mcdaniel JM, Shannon DA, CM J (2009) A multilevel analysis of the determinants of forest conservation behaviour among farmers in Haiti. Soc Nat Resour 22:433-447

Espinoza G (2010) Evaluación ambiental estratégica de apoyo al sistema nacional de áreas protegidas. Proyecto MMA / GEF-PNUD "Creación de un Sistema Nacional Integral de Áreas Protegidas para Chile: Estructura Financiera y Operacional"., p 223, URL: http://www.proyectogefareasprotegidas.cl/wp-content/uploads/ 2011/09/evaluacion\%20estrategica.ok.pdf

Franklin WL, Johnson WE, Sarno RJ, Iriarte JA (1999) Ecology of the Patagonia puma Felis concolor patagonica in southern Chile. Biol Conserv 90:33-40, doi:33

Glade A (1993) Libro rojo de los vertebrados terrestres de Chile. Corporación Nacional Forestal, Santiago, Chile

Grez AA (2005) El valor de los fragmentos pequeños de bosque maulino en la conservación de la fauna de coleópteros epigeos. In: Smith-Ramírez C, Armesto JJ, Valdovinos C (eds) Historia, biodiversidad y ecología de los bosques de la Cordillera de la Costa: 565-572. Editorial Universitaria, Santiago, Chile

Grez AA, Simonett JA, Bustamante RO (2006) Biodiversidad en ambientes fragmentados de Chile: patrones y procesos a diferentes escalas. Editorial Universitaria, Santiago, p 229

Leong KM (2010) The tragedy of becoming common: landscape change and perceptions of wildlife. Soc Nat Resour 23:111-127

Lucherini M, Merino MJ (2008) Perceptions of human-carnivore conflicts in the high Andes of Argentina. Mt Res Dev 28:81-85

Mc Cleery RA (2009) Improving attitudinal framework to predict behaviour in human-wildlife conflicts. Soc Nat Resour 22:353-368

Mella J, Simonetti J (1994) Representación de poblaciones viables: Conservación de mamíferos en las áreas silvestres protegidas de Chile. Ambiente y Desarrollo 10:72-78

Messmer TA (2009) Human-wildlife conflicts: emerging challenges and opportunities. Hum Wildl Conflicts 3:10-17

Mobley C, Deward WM, Vagias SL (2010) Exploring additional determinants of environmentally responsible behavior: the influence of environmental literature and environmental attitudes. Environ Behav 42:420-447

Moon K, Cocklin C (2011) A landholder-based approach to the design of private-land conservation programs. Conserv Biol 25:493-503

Muñoz M, Núñez H, Yáñez J (1996) Libro rojo de los sitios prioritarios para la conservación de la diversidad biológica en Chile. Corporación Nacional Forestal, Chile

Muñoz-Concha D, Garrido-Werner A (2011) Ethnobotany of gomortega keule, an endemic and endangered Chilean tree. N Z J Bot 49:509-513

Myers N, Mittermeier RA, Mittermeier CG, Fonseca GABDA, Kent J (2000) Biodiversity hotspots for conservation priorities. Nature 403:853-858

Nahuelhual L, Carmona A, Lara A, Echeverría C, González ME (2012) Land-cover change to forest plantations: proximate causes and implications for the landscape in south-central Chile. Landsc Urban Plan 107:12-20

Pauchard A, Villarroel P (2002) Protected areas in Chile: history, current status, and challenges. Nat Areas J 22:318-330
Poudyal NC, Hodges DG (2009) Factors influencing landowner interest in managing wildlife and avian habitat on private forestland. Hum Dimens Wildl 14:240-250

Raymond L, Olive A (2008) Landowner beliefs regarding biodiversity protection on private property: an Indiana case study. Soc Nat Resour 21:483-497

Servicio Agricola Y Ganadero (SAG) (2012) La ley de caza y su reglamento. Servicio Agrícola y Ganadero, Ministerio de Agricultura, Chile

Sanderson J, Sunquist ME, Iriarte A (2002) Natural history and landscape-use of guignas (Oncifelis guigna) on Isla Grande de Chiloé, Chile. J Mammal 83:608-613

Sepúlveda C (2004) ¿Cuánto hemos avanzado en conservación privada de la biodiversidad?: el aporte de las Áreas Protegidas Privadas en perspectiva. Revista Ambiente y Desarrollo 20:75-79

Silva-Rodríguez EA, Soto-Gamboa M, Ortega-Solís GR, Jiménez JE (2009) Foxes, people and hens: human dimensions of a conflict in a rural area of southern Chile. Rev Chil Hist Nat 82:375-386

Simonetti JA (1994) Threatened biodiversity as an environmental problem in Chile. Rev Chil Hist Nat 67:315-319

Simonetti JA (2006) Conservación de la biodiversidad en ambientes fragmentados: el caso del bosque maulino. In: Grez AA, Simonetti JA, Bustamante RO (eds) Biodiversidad en ambientes fragmentados de Chile: patrones y procesos a diferentes escalas: 215-231. Editorial Universitaria, Santiago, Chile

Squeo F, Estévez RA, Stoll A, Gaymer CF, Letelier L, Sierralta L (2012) Towards the creation of an integrated system of protected areas in Chile: achievements and challenges. Plant Ecol Divers. doi:10.1080/17550874.2012.679012

Stoll A, Sepúlveda C, San Martín J (2006) Patrón florístico-estructural de la vegetación nativa remanente en el límite norte del Bosque Templado Costero de Chile: el caso de la quebrada Cayurranquil (VII Región, Chile). Bosque 27:64-71

Wallace GN, Theobald DM, Erns T, King K (2008) Assessing the ecological and social benefits of private land conservation in Colorado. Conserv Biol 22:284-296

\section{doi:10.1186/0717-6317-87-4}

Cite this article as: Zorondo-Rodríguez et al: Conservation of biodiversity in private lands: are Chilean landowners willing to keep threatened species in their lands? Revista Chilena de Historia Natural 2014 87:4.

\section{Submit your manuscript to a SpringerOpen ${ }^{\circ}$ journal and benefit from:}

- Convenient online submission

- Rigorous peer review

- Immediate publication on acceptance

- Open access: articles freely available online

- High visibility within the field

- Retaining the copyright to your article

Submit your next manuscript at springeropen.com 